\title{
A Brief Analysis on the Main Course Books Music Theory in Turkey
}

\author{
Rohat Cebe \\ Batman University, Faculty of Fine Arts, Department of Music, Batman, Turkey \\ E-mail: rohat.cebe@batman.edu.tr
}

\begin{abstract}
Music education and music form the basis of a basic course in whichevery branch on Basic Music Theorycourse, is one of the most important areas of musice ducation. Basic Music Theory course of theoretical and practical sections of music education constitutes an important place in the development of each musician. This course is literally ingrain edenthusiasm for music of all individual sapplying for learning music is one of the most important resources. Music Theory lessons written in Turkish or translation made about the educational valuere mains today a variety of sources. However, this book does not include a common language, literally. Caused conflicts of concept sand terms to be the case, the issue sarefully understanding delay. Declaration of basic music theory in our country starting from text boks related tothes edeficiencies detecte dandregulations necessary in advancing the process of making concrete analysis of what could happen is open to debate.
\end{abstract}

Keywords: Music, Music Education, Basic Music Theory.

\section{Special Issue of Educational Sciences}

DOI: $10.7176 / J S T R / 6-06-13$

\section{Türkiye'deki Temel Müzik Teorisi Ders Kitapları Üzerine Kısa Bir Analiz}

Bu makale 26-28 Nisan 2019 yılında Diyarbakır'da düzenlenen Anadolu 2. Uluslararası Sosyal Bilimler Kongresinde sözlü olarak sunulmuş ve Kongre Kitabında tam metin olarak yayınlanmıştır.

Özet

Müzik eğitiminin temelini oluşturan ve müzik ile ilgili her bölüm de temel bir ders olan Temel Müzik Teorisi dersi, müzik eğitiminin en önemli alanlarından biridir. Temel Müzik Teorisi dersinin kuramsal ve uygulamalı bölümleri müzik eğitimi alan her müzisyenin gelişiminde önemli bir yer teşkil eder. Bu ders genel anlamıyla müziğe heves salmış tüm bireylerin müziği öğrenmeleri için başvurdukları en önemli kaynaklardan biridir. Müzik Teorisi dersiyle ilgili Türkçe yazılmış veya çevirisi yapılmış çeşitli kaynaklar günümüzde eğitici değerini korumaktadır. Ancak bu kitaplar tam anlamıyla ortak bir dil içermemektedir. Kavram ve terim karmaşası yaşanmasına sebep olunan bu durum, konuların tam olarak anlaşılmasını da geciktirmektedir. Bildiri ülkemizdeki temel müzik teorisi ders kitaplarından yola çıkarak bu alanla ilgili eksikliklerin tespit edilmesini ve ilerleyen süreç içerisinde yapılması gereken düzenlemelerin neler olabileceğini somut analizler yaparak tartışmaya açacaktır.

Anahtar Kelimeler: Müzik, Müzik Eğitimi, Temel Müzik Teorisi Dersi.

\section{Giriș}

Müziğin uyduğu kuralları inceleyen bilim dalına Müzik Teorisi denir. Bu bilim bize, sesleri, seslerin şekli ve değerler niteliklerini, bu sesler arasındaki ilgiyi öğretir. Müzik duygu dilidir. Kelimelerle anlatamadığımız duygu ve düşüncelerimizi belirli kurallara göre seslerle anlatma sanatıdır (Çalışır, 1969: 1). Dilbilgisinde nasıl kurallar ve kaideler var ise müziğin aktarılmasında da kural ve kaideler vardır. Müzik 
sanatında işlevsel olarak bunun sağlanmasını öğreten ders Müzik Teorisi dersidir. Bu ders müzik eğitiminin en temel dersi konumundadır. Müzik dinlemekten hoşlanan ama müziğin dilinden anlamayan bir müzik sever, tatilini geçirmek için gittiği bir ülkenin doğal güzelliklerini gören, o ülke halkının davranış biçimlerine tanık olan, konuşmalarını dinleyen ama söylenenlerin tek bir sözcügünü bile anlamayan bir turiste benzer (Karolyi, 2014: 7). Müzik diline hakim olan bir müzik sever ise dinlediği müzikte teknik olarak ne olup bittiğini kolayca anlayabilir. Müzik teorisi dersi müziğin alfabesi niteliğindedir. Bu açıdan okuma yazma bilmeyen bir öğrenci sırasıyla harfleri, heceleri, kelimeleri öğrenip en sonunda cümle kurmayı öğreniyorsa Müzik Teorisi öğrenen bir bireyin de önce sesleri ve süreleri sonra bu ses ve sürelerin ritimlerinidaha sonra ise ses ve sürelerinin dinamiklerini öğrenmesi gerekmektedir. Müzik Teorisi dersi kötü olan bir öğrenci ya da müzisyen alanında başarılı olamayacaktır. Bu açıdan Müzik Teorisi dersi müzik sanatının en temel ve önemli derslerinden biridir. Müzik teorisi öğrenmek isteyen bir birey ilk olarak herhangi bir müzik teorisi kitabına ulaşmak ve konuları detaylı bir şekilde anlamak ister. Ülkemizde yayınlanmış yaklaşık olarak otuza yakın Müzik Teorisi kitabı bulunmaktadır. Bu kitaplardan bazıları çeviridir. Ancak kitaplardaki konu aktarımı ve bütünsel farklılıklar Müzik Teorisi öğretiminde aksaklıklara neden olmaktadir.

\section{Müzik Teorisi Kitaplarının İçerikleri}

Müziğin ana malzemesi sestir. Ses, titreşebilen bir maddenin (ör. gerilmiş bir tel) gerekli enerjiyi sağlayan bir uyarıcı tarafindan harekete geçirilmesi ile oluşur (Göktepe: 2014: 7). Sesin yüksekliği (ince ye da kalın oluşu), gürlüğü (hafif ya da kuvvetli oluşu), niteliği (bir sesin farklı çalgılara ya da farklı insan seslerine göre taşıdığı renk), entonasyon (ses yüksekliklerini şaşmaz bir doğrulukla verebilme becerisi) Müzik Teorisi dersini ilk konularıdır. İncelenen birçok teori kitabı ilk olarak bu konuyu ele almışken bazı kitaplar bu konu üzerinde durmamış, direk olarak müzik yazısı yani notaları öğretme konusuna yoğunlaşmışlardır. Sesin niteliklerini bilmeyen bir öğrencinin sesi doğru ve istenilen bir biçimde uygulamaya dökmesi tartışma yaratabilir.

Feridun Çalışır'ın 1969 yılında yazdığı 'Müzik Teorisi' adlı kitabı genel olarak, Müzik, Müzik Teorisi, Müzik Yazısı, Nota konularıyla başlayıp İnsan Sesleri, Ölçü, Vuruş, Ritim, Müzik Yazısında Kısaltmalar, Nüans, Mod, Aralıklar, Tonaliteler, Modülasyon, Çalg1 Müziği, Söz Müziği, Koro, Akor Bilgisi, Türk Müziği, Nefesli Müzik Çalgıları, Metronom Hakkında Kısa Bilgi ve Sözlük konularını kapsamaktadır.

Ahmet Adnan Saygun'un Milli Eğitim Bakanlığı Talim ve Terbiye Kurulunun 14 Eylül 1964 tarih ve 216 sayılı kararı ile Konservatuvar Yayınları Serisinde yayımlanması uygun görülmüş ve Yayım Müdürlüğünün 16 Ekim 1964 tarih ve sayılı emriyle defa olarak 3000 adet olarak basılmış dört kitaptan oluşan 'Musiki Temel Bilgisi’ adlı serisinin 1971 yılında ikinci baskısı yayınlanan'Musiki Temel Bilgisi (Kitap I)’ adlı kitabı genel olarak, Zamanın Sayılması konusuyla başlayıp, Ölçü Zamanlarının Sayılması, Tartı, Metronom, Süre Değerleri, Dizi, Perde, Değiştirici İşaretler, Piyano ve Çeşitleri, Nüans Terimleri, Hız Terimleri, Zamanın Bölünmesi ve Tonaliteler konularını kapsamaktadır.

Ahmet Adnan Saygun'un 1970 yılında ikinci baskısı yayınlanan 'Musiki Temel Bilgisi (Kitap III)' adlı kitabı genel olarak, Ses, Titreşim, Aralık, Seslerin Birbirini Çekmesi, Üç Sesten Meydana Gelen Topluluklar, Uyuşum ve Çekim, Dengeserlik, Majör Dengeserlik, Minör Dengeserlik, Aralıkların Çevrilmesi, Aktarmak, Aktarım ve Terimler Cetveli konularını kapsar.

Ahmet Adnan Saygun'un 1966 yılında yayınlanan 'Musiki Temel Bilgisi (Kitap IV)'adlı kitabı genel olarak, Doğuşkanlar, Zaman, Vurgulama, Tartı, Konuşmada Vurgu, Serbest Tartılar, Musiki, Arı̆̆ Musiki, Sözlü Musiki, Tasvir Musikisi, Musikinin Unsurları, Melodinin Niteliği, Melodi Gözesi, Cümle, Dengesel Musıkide Melodinin Özellikleri, Armoni, Armonilemek, Düzen, Dengesel Musikide Cümle, Dengesel Musiki Dışındaki Musikiler, Töreler, Töresel Musiki, Dor Töresi, Töresel Musikide Töre Değişimi konularını kapsamaktadır. Bu açıdan kitap müzik teorisi kitabı olmanın yanında içerdiği konular açısından Form Bilgisi, Armoni ve Töresel Müzik derslerine de kaynak olabilecek niteliktedir.(Serini ikici kitabına ulaşılamamıştır).

Eduard Zuckmayer'in ders notlarının Nurhan Cangal ve Adnan Atalay tarafindan düzenlenmesiyle oluşturulan ve 1976 yılında yayınlana 'Müzik Teorisi (Armoni ve Kontrpuan)' adlı kitabının amaçlar kisminda;

1. Birarada tınlayan seslerin (uygusal ya da ezgisel olarak) anlamının ne olduğunu ve birbirleriyle ilişkilerinin anlaşılmasını sağlamak,

2. Bugüne kadar yazılmış sanat yapıtlarının çözümlemelerini (analizini) yapabilmek ve bu yolla onları daha iyi tanıyabilmek ve anlayabilmek,

3. Çokseslilik duygusunu kazanmak,

4. Besteleme bilgisi, beceri ve yeteneğini geliştirerek yeni yapıtlar ortaya koymak,

$\mathbf{1 8 0} \mid \mathrm{P}$ a g e

www.iiste.org 
5. Bazı tek sesli parçaları ele alarak, onları öğrenilen kurallar içinde işleyip çok sesli hale getirmek,

6. Kazanılan bilgi ve becerilerin ışı̆̆ı altında, henüz kesinlik kazanmamış, araştırma ve uygulama durumunda olan TÜRK MÜZİĞİ çoksesliliği gelişmesine katkıda bulunmak,

Altı maddeyle kitabın içeriği ve amaçlananın ne ya da neler olduğu ifade edilmeye çalışılmıştır. Bu açıdan bu kitapta temel müzik teorisi öğretisinden öte Armoni, Kontrpuan ve Kompozisyon derslerinin konularını kapsamaktadır.

Ahter Destan'ın çevirisini yaptığı Paraşkev Haciev'in 'Temel Müzik Teorisi' adlı kitabı; Temel Kavramlar, Seslerin Yazılışı, Ritim, Metrum, Ölçü Sayısı, Ölçü, Aralıklar, Mod, Gam, Tonalite, Süslemeler, Nota Yazımında Kısaltmalar, Artikülasyon, Akorlar, İtalyan Müzik Terimlerinin Kısa Sözlüğü konularını kapsar.

Mehmet Emin Göktepe'nin 2014 yılında yazdığı 'Müzikte Ses Süre Hız Yoğunluk' adlı kitabı; Seslerin Yapısı, Seslerin Adları, Seslerin Notalarla Gösterilişi, Aralık, Çalgılar, Süre, Ritim, Tartım, Dönemsellik, Hız, Yoğunluk, Müzik Cümleleri ve Sözlük konularını kapsamaktadır.

Mehmet Nemutlu'nun çevirisini yaptığı OttoKarolyi'nin 'Müziğe Giriş' adlı kitabı; Sesler ve Simgeler, Armoni ile Kotrpuan, Müzik Biçimleri, Çalgılar İle İnsan Sesi, Partisyonlar ile Partisyon Okuma konularını kapsamaktadır. Bu açıdan kitap müzik teorisi öğretisinin ötesinde Müzik Tarihi dersi hariç teorik olan bütün müzik derslerinin konularını içerisinde barındırmaya çalışmıştır.

Vicdan Tabakoğlu'nun 'Bona Müzik Teorisi Notları' adlı kitabı; Nota, İnsan Sesi, Süre, Gam, Tam SesYarım Ses, Ölçü, Değiştirme İşaretleri, Müzik Yazısında Kısaltmalar, Nüans, Mod, Tonalite, Aralıklar, Bir Müzik Parçasının Tonunun Bulunuşu, Aktarma, Süsleme, Kadans, Akor, Türk Musikisi Müzik Teorisi Özet Notları konularına kısaca değindikten sonra ritmik çalışmalar ışığında bona okumayı öğretmeyi amaçlayan bir kitaptir.

Alphonse Danhauser'den genişleterek Türkçeye İlhan Baran tarafından uygulanan 'Temel Müzik Kuramları' adlı kitap; Müzik Yazmak İçin Kullanılan İşaretler, Dizi ve Aralıklar, Tonalite, Ölçü, Ayırtı ve Anlatım konularına kısaca değinmiştir.

\section{Sonuç}

Genel olarak bakıldığında müzik teorisi ders kitaplarında olması gereken bütün konular incelenen kitaplarda anlatılmaya çalışılmıştır. Konuların çokluğu ve kitaplar içerisinde ki sıralanması farklılıklar göstermektedir. Bazı kitaplar müzik teorisinin yanında armoni, form bilgisi, çalgı bilgisi derslerine ait konuları da içerisinde barındırmaktadır. 1960'lı ve 1970'li yıllarda yazılan teori kitaplarında kullanılan dil daha edebidir. $\mathrm{Bu}$ açıdan anlaşılma zorlukları yaşanabilmektedir. Çevirisi yapılan kitaplardaki aktarım ve konuların incelenmesi daha sade ifadelerle anlatılmaya çalışılmıştır.

Konular geniş bir yelpazede değerlendirildiği için ince detaylara değinilememiştir. Bu da konuları anlamaya çalışan bireylerin ya da öğrencilerin ilk okuyuşta anlamalarına olanak sağlamamaktadır. Detaylandırılarak yapılacak değerlendirmeler ve basite indirgenecek örnekler bu sorunu ortadan kaldıracaktır.

Müzik Teorisi dersi müzik eğitiminin temelini oluşturmaktadır. Bu ders müzik ile ilgili birçok dersin anlaşılabilmesine zemin sağlamaktadır. Müzik teorisi öğretisinin eksik kalması müzik ile uğraşan bireyin müzik ile ilgili birçok dersi anlayamamasını sağlayacaktır. Bu değerlendirmeler ışığında konuların belirli bir bütünlük içerisinde sıralandığı, tüm bireylerin kolayca anlayabileceği sade bir Müzik Teorisi kitabına ihtiyaç duyulduğu kanaati oluşmuştur.

\section{Kaynakça}

Danhauser, Alphonse., Baran, İlhan. (1985). Temel Müzik Kuralları, Belgi Yayınları, Ankara.

Çalışır, Feridun. (1969) Müzik Teorisi, K. K. K. Askeri Basımevi, İstanbul.

Göktepe, M. Emin. (2014). Müzikte Ses Süre Hız Yoğunluk, Phoenix Yayınevi, Ankara.

Haciev, Paraşken. (2007). Temel Müzik Teorisi, Çeviren: Ahter Destan, Pan Yayıncılık, İstanbul.

Karolyi, Otto. (2007). Müziğe Giriş, Çeviren: Mehmet Nemutlu, Pan Yayıncılık, İstanbul. 
International Journal of Scientific and Technological Research

ISSN 2422-8702 (Online), DOI: 10.7176/JSTR/6-06-13

Special Issue of Educational Sciences, Vol.6, No.6, 2020

Saygun, A. Adnan. (1971). Musıki Temel Bilgisi Kitap I (Musıki Nazariyatı), İkinci Basılış, Milli Eğitim Basımevi, İstanbul.

Saygun, A. Adnan. (1970). Musıki Temel Bilgisi Kitap III (Musıki Nazariyatı), İkinci Basılış, Milli Eğitim Basımevi, İstanbul.

Saygun, A. Adnan. (1966). Musıki Temel Bilgisi Kitap IV (Musıki Nazariyatı), Milli Eğitim Basımevi, İstanbul.

Tabakoğlu, Vicdan. (-). Bona Müzik Teorisi Notları, Kıvılcım Yayınları, Ankara.

Zuckmayer, Eduard., Cangal, Nurhan., Atalay, Adnan. (1976) Müzik Teorisi (Armoni ve Kontrpuan), Yaykur Açık Yükseköğretim Dairesi, Ankara. 